\title{
Karakteristik Fermentasi Rumen dan Keseimbangan Nitrogen Domba yang Diberi Minyak Kanola Murni dan Terenkaspulasi
}

\author{
Mawar $^{1 *}$, I Komang Gede Wiryawan ${ }^{2}$, Sri Suharti ${ }^{2}$ \\ Departemen Ilmu Nutrisi dan Teknologi Pakan, IPB University (Institut Pertanian Bogor) \\ Jalan Agatis, Kampus IPB Dramaga, 16680, Bogor, Indonesia \\ *Email korespondensi: harti_ss@yahoo.com
}

(Diterima: 25-07-2019; disetujui 20-08-2019)

\begin{abstract}
ABSTRAK
Penelitian ini bertujuan untuk menganalisis pengaruh minyak kanola tanpa proteksi dan terenkapsulasi pada karakteristik fermentasi rumen. di domba garut jantan. Penelitian menggunakan rancangan acak kelompok (RAK) dengan rancangan 3 perlakuan dan 5 kelompok sebagai ulangan. Perlakuan terdiri dari P0 (kontrol/pakan ternak:konsentrat $=60: 40$ ), P1: P0 (mengandung minyak kanola 4\% dari total ransum); P2: P0 (mengandung mikroenkapsulasi minyak kanola 4\% dari total ransum). Bahan pelapis yang digunakan dalam produk mikroenkapsulasi memiliki komposisi 50\% maltodekstrin dan 50\% gum arab. Data dianalisis menggunakan analisis sidik ragam. Hasil penelitian menunjukkan penambahan minyak kanola bebas maupun minyak kanola proteksi pada ransum sangat nyata $(\mathrm{P}<0,01)$ menurunkan populasi protozoa. Sintesis protein bakteri, $\mathrm{NH}_{3}$, retensi nitrogen, dan kadar BUN sangat nyata meningkat $(\mathrm{P}<0,01)$ pada pemberian minyak kanola bebas. Sementara penurunan terjadi pada pemberian minyak kanola terenkaspulasi dibandingkan kontrol. Namun, penambahan $4 \%$ minyak kanola bebas dan terenkapsulasi tidak signifikan mempengaruhi populasi bakteri total dan VFA. Dapat disimpulkan bahwa penambahan minyak kanola tanpa proteksi memberikan produksi NH3, BUN, dan SPM tertinggi di rumen serta minyak kanola dalam bentuk bebas dan terenkaspulasi mampu menurunkan pertumbuhan protozoa rumen yang merupakan predator bakteri tetapi tidak dapat menstimulasi pertumbuhan populasi bakteri rumen.
\end{abstract}

Kata Kunci: mikroenkapsulasi, minyak kanola, rumen, spm, total bakteri

\section{ABSTRACT}

This experiment aimed to investigate the effects of unprotected and microencapsulated canola oil on rumen fermentation characteristics in Garut young rams. The design of experiment was using randomized block design (RBD) with 3 treatments and 5 groups as replication. The treatments were $\mathrm{T} 0$ (control/forage: concentrate $=60: 40), \mathrm{T} 1=\mathrm{T} 0$ (Contain canola oil 4\% total diet), T2 T0 (Contain microencapsulated canola oil (4\% total diet). Coating materials composition used in microencapsulation were 50\% maltodextrin and 50\% arabic gum. The data were analyzed by using analysis of variance (ANOVA). The results showed that addition either protected or unprotected of canola oil on diet significantly $(\mathrm{P}<0.05)$ decreased rumen protozoa population. Microbial protein synthesis (MPS), $\mathrm{NH}_{3}$ nitrogen retention, and BUN were significantly $(\mathrm{P}<0.01)$ increased in unprotected canola oil meanwhile was decreased in the microencapsulated. Nonetheless, addition $4 \%$ of protected or unprotected canola oil did not significantly affect total bacterial population and VFA. It is concluded that addition of the unprotected canola oil gave the highest production of $\mathrm{NH}_{3}, \mathrm{BUN}$, and MPS in rumen. In addition, the use of unprotected and microencapsulation of canola oil reduced the population of protozoa which are the predators of bacteria, but could not stimulate the growth population of rumen bacteria.

Keywords: beef, diversification, development strategy, population 


\section{PENDAHULUAN}

Pencernaan fermentatif rumen melibatkan beragam mikroba dengan fungsi berbeda dan berperan dalam mencerna pakan berserat yang berkualitas rendah serta sebagai salah satu sumber protein utama bagi induk semang melalui sintesis protein bakteri rumen. Metabolisme mikroba di dalam rumen diatur oleh jumlah dan kecepatan degradasi karbohidrat dan protein. Kondisi ini sangat dipengaruhi oleh karakteristik fisik dan kimia pakan (Maeng et al., 1997). Pemenuhan kebutuhan nutrisi ternak ruminansia sangat diperlukan untuk mendukung aktivitas mikroba rumen maupun ternak itu sendiri Pemenuhan kebutuhan energi akan sulit dilakukan pada ternak ruminansia yang diberi hijauan dengan proporsi tinggi karena tingginya serat kasar serta rendahnya kualitas hijauan pada daerah tropis yang fluktuatif. Suplementasi lemak dalam formulasi pakan merupakan alternatif yang banyak digunakan pada pakan ternak pedaging. Menurut Soebarinoto et al. (1991) penggunaan lemak dapat meningkatkan energi ransum dan memodifikasi asam lemak jaringan tubuh ruminansia serta Wina dan Susana (2013) asam lemak akan menghasilkan energi yang lebih tinggi bahkan dua kali lebih besar dari energi karbohidrat (NRC, 2001). Menurut Hess et al. (2008), suplementasi lemak pada ransum menjadi strategi yang menjanjikan untuk meningkatkan efisiensi pada produksi ternak dengan meningkatkan kerapatan energi ransum.

Minyak kanola memiliki karakteristik asam lemak jenuh yang sangat rendah, karena tingginya level asam lemak tidak jenuh tunggal (MUFA) dan dan asam lemak tidak jenuh jamak (PUFA). Maia (2012) melaporkan kandungan asam lemak oleat, linoleat dan linolenat masing-masing sebesar 57,4\%;17,3\%; dan 5,3\%. Menurut Tiven et al. (2011), tingginya lemak tidak jenuh dalam pakan relatif tidak bertahan karena adanya proses biohidrogenasi lemak tersebut oleh mikroba rumen menjadi asam lemak jenuh. Proses tersebut dilakukan karena sifat toksik dari asam lemak tidak jenuh bagi sebagian besar mikroba rumen. Biohidrogenasi akan mengubah karakteristik asam lemak pakan yang tidak jenuh menjadi jenuh sehingga yang akan masuk dalam pencernaan selanjutnya dan diserap oleh ternak menjadi tinggi kandungan asam lemak jenuh. Oleh karena itu penggunaan minyak yang tinggi akan asam lemak tidak jenuh harus diproteksi untuk mencegah dari biohidrogenasi di dalam rumen. Salah satu teknologi yang banyak digunakan yaitu proteksi dengan penyalutan minyak nabati (Bhatt et al., 2013; Hidayah et al., 2014; Bain et al., 2014). Hidayah (2014) melaporkan bahwa penggunaan metode proteksi pada minyak nabati memberikan efek positif terhadap aktifitas mikroba rumen dibandingkan tanpa diproteksi. Adawiah et al. (2007) melaporkan bahwa penambahan lemak dalam bentuk sabun kalsium dapat meningkatkan produk fermentasi mikroba rumen. Selain sabun kalsium, salah satu teknologi proteksi yang dapat digunakan untuk penyalutan bahan inti melalui proses kimiawi yaitu mikroenkapsulasi (Agnihotri et al., 2012). Penggunaan mikroenkapsulasi dilaporkan digunakan untuk menyalut ekstra virgin olive oil (Calvo et al., 2010); cumin oleoresin (Kanakdande et al., 2007) dan minyak esensial (Soltan et al., 2018). Penggunaan mikroenkapsulasi minyak kanola secara in vitro dilaporkan Hidayah dengan menggunakan cairan rumen sapi persilangan ongole dan Bain et al. (2014) menggunakan cairan rumen sapi bali Belum banyak laporan terkait penggunaan mikroenkpasulasi terhadap karakteristik rumen, SPM, serta retensi nitrogen terutama menggunakan minyak kanola pada domba secara in vivo.

Tujuan dari penelitian ini untuk menganalisis pengaruh pemberian minyak kanola sebagai sumber tambahan lemak dalam bentuk mikroenkapsulasi maupun tidak diproteksi terhadap karakteristik fermentasi rumen, sintesis protein mikroba dan nilai retensi nitrogen.

\section{MATERI DAN METODE}

\section{Metode Penelitian}

Penelitian dilaksanakan di Laboratorium lapang (Kandang) A bagian Ruminansia Kecil Departemen INTP, Fakultas Peternakan, Institut Pertanian Bogor (IPB). Domba garut jantan berumur 6-8 bulan digunakan sebanyak 15 ekor dengan rataan bobot badan awal 20,17 $\pm 4,65 \mathrm{~kg}$. Ternak dibagi menjadi 5 ulangan dalam 3 perlakuan. Dilakukan pemberian obat cacing sebelum pemeliharaan Ternak dipelihara dalam kandang individu selama 100 hari dengan 14 hari masa adaptasi. Perlakuan terdiri atas P0: Ransum kontrol (60\% hijauan:40\% konsentrat); P1: P0 + minyak kanola 4\% dari total ransum); P2: P0 + mikroenkapsulasi minyak kanola $4 \%$ dari 
total ransum). Ransum diformulasikan sesuai dengan kebutuhan domba pedaging yang ditujukan untuk peningkatan pasokan produksi daging. Proporsi ransum yaitu 60\% hijauan berupa rumput gajah dan $40 \%$ konsentrat yang terdiri atas bungkil kedelai, bungkil kelapa, pollard, jagung, molases, urea, DCP, dedak halus, bungkil kelapa sawit, minyak kanola, dan mikroenkapsulasi minyak kanola yang kebutuhannya (Tabel 1) diacu pada Kearl et al. (1982). Pembuatan mikroenkapsulasi ransum mengacu pada Carneiro et al. (2013) yaitu dilakukan homogenisasi bahan penyalut $(11,76 \%)$ berupa gum arab dan maltodekstrin (50:50) serta air $(82,36 \%)$ kemudian dicampurkan dengan minyak kanola $(5,88 \%)$ lalu dikeringkan menggunakan spray dryer pada suhu inlet $180 \pm 5^{\circ} \mathrm{C}$ dan outlet $80 \pm 5^{\circ} \mathrm{C}$. Frekuensi pemberian pakan dilakukan sebanyak dua kali pada jam 08.00 WIB dan jam 13.00 WIB dengan air minum diberikan ad libitum.

\section{Pengambilan dan Analisis Data}

Pengambilan darah dan cairan rumen dilakukan pada waktu 4 jam setelah pemberian pakan pagi (after morning feeding) di dua hari berbeda pada hari terakhir pemeliharaan. Feses dan urin dikompositkan masing-masing $10 \%$ setiap harinya pada masa koleksi selama tujuh hari di akhir masa pemeliharaan dan. Pengambilan darah sebanyak $5 \mathrm{~mL}$ dilakukan pada vena jugularis kemudian dimasukkan ke dalam tabung berisi antikoagulan EDTA kemudian disentrifugasi selama 15 menit dengan kecepatan 300 RPM untuk mendapatkan plasma darah. Kadar blood urea nitrogen diukur dengan menganalisis plasma darah domba dengan menggunakan KIT merk PT. Rajawali Nusindo Reg. No: AKL 20101804026 dan microlab 300 berdasarkan reaksi enzimatis kemudian dilakukan pengukuran menggunakan spektrofotomoter $578 \mathrm{~nm}$. Cairan rumen diambil menggunakan metode stomach tube (Preston 1986) dengan memasukkan selang stomach tube hingga bagian rumen domba melalui mulut domba lalu mesin vakum yang telah terhubung dihidupkan untuk menghisap cairan rumen ke dalam botol vakum. Pengukuran $\mathrm{pH}$ rumen dilakukan menggunakan alat $\mathrm{pH}$ meter. Populasi protozoa ditentukan menggunakan counting chamber Fuch Rosenthal Counting (4mm x $4 \mathrm{~mm} \times$ $2 \mathrm{~mm}$ ) yang sebelumnya cairan rumen diwarnai dengan larutan Tryphan Blue Formaline Salin (TBFS) (1:1). Perhitungan populasi bakteri total mengacu pada metode Ogimoto dan Imai (1981) menggunakan media BHI dan metode roller tube. Cairan rumen untuk analisis konsentrasi VFA total dan proporsi molar VFA (asam asetat, propionat, butirat, iso butirat, valerat, dan iso valerat) sebelumnya ditetesi $\mathrm{H}_{2} \mathrm{SO}_{4}$ kemudian dianalisis menggunakan teknik gas kromatografi (General Laboratory Procedures 1966) (GC 8A, Shimadzu Crop., Kyoto, Japan, tipe Capillary column mengandung $10 \%$ SP-1200, $1 \% \mathrm{H}_{3} \mathrm{PO}_{4}$ dalam 80/100 Cromosorb WAW dan nitrogen sebagai carrier gas). Pendugaan produksi gas metan dari proporsi molar VFA berdasarkan rumus menurut Moss et al. (2000) $\left(\mathrm{CH}_{4}=0.45 \mathrm{C}_{2}-\right.$ $0.275 \mathrm{C}_{3}+0.40 \mathrm{C}_{4}$ ) dan pendugaan perhitungan keseimbangan hidrogen dari proporsi molar VFA berdasarkan rumus menurut Mitsumori et al. (2012) [2HP (Produksi Hidrogen dari pembentukan asam lemak rantai pendek) $=2 \mathrm{x}$ $\mathrm{C}_{2}+\mathrm{C}_{3}+4 \mathrm{x} \mathrm{C}_{4}+2 \mathrm{x} \mathrm{Ci}_{5}+2 \mathrm{x} \mathrm{C}_{5}$ ] dan [2HUS (Penggunaan Hidrogen dari pembentukan asam lemak rantai pendek) $=2 \times \mathrm{C}_{3}+2 \mathrm{x} \mathrm{C}_{4}+\mathrm{C}_{5}$ ] Konsentrasi amonia $\left(\mathrm{N}-\mathrm{NH}_{3}\right)$ diukur menggunakan metode mikrodifusi Conway berdasarkan (General Laboratory Procedures 1966). Perhitungan sintesis protein mikroba menggunakan metode Makkar et al. (1982) hingga didapatkan supernatan kemudian dilanjutkan dengan metode Lowry's et al. (1951) hingga didapatkan nilai absorbansinya pada spektrofotometer $670 \mathrm{~nm}$. Protein ransum, feses dan urin dianalisis menggunakan metode Kjeldhal melalui proses destruksi, destialsi, titrasi dan perhitungan. Peubah yang diamati dalam penelitian ini antara lain: VFA parsial, $\mathrm{NH}_{3}, \mathrm{pH}$ cairan rumen, populasi bakteri total, populasi protozoa, kadar blood urea nitrogen $(\mathrm{BUN})$, retensi nitrogen, dan sintesis protein mikroba.

\section{HASIL DAN PEMBAHASAN}

\section{Populasi Mikroba Rumen}

Penambahan minyak kanola dengan proteksi mikroenkapsulasi maupun tanpa proteksi tidak mempengaruhi populasi bakteri total (Tabel 2) di dalam rumen domba. Berbeda dengan populasi bakteri total, populasi mikroba rumen lainnya yaitu protozoa (Tabel 2) secara nyata $(\mathrm{P}<0,05)$ menurun dengan adanya penambahan perlakuan. Populasi pada penelitian ini sesuai dengan Ogimoto \& Imai (1981) yang menyatakan populasi 
Tabel 1. Komposisi bahan pakan penyusun ransum domba pedaging fase penggemukan

\begin{tabular}{lccc}
\hline \multicolumn{1}{c}{ Jenis Ransum } & $\mathrm{P} 0$ & $\mathrm{P} 1$ & $\mathrm{P} 2$ \\
\cline { 2 - 4 } & & $\%$ & 60,0 \\
Rumput gajah & 60,0 & 60,0 & 0,0 \\
Bungkil Kedelai & 0,0 & 4,1 & 0,2 \\
Urea & 0,2 & 0,2 & 0,0 \\
Jagung & 8,0 & 0,0 & 0,3 \\
DCP & 0,3 & 0,3 & 0,0 \\
Dedak Halus & 0,0 & 8,0 & 12,0 \\
Bungkil Kelapa & 12,0 & 2,2 & 10,0 \\
Bungkil Kelapa Sawit & 4,2 & 8,8 & 3,4 \\
Molases & 4,0 & 4,0 & 4,0 \\
Mikroenkapsulasi Minyak Kanola & 0,0 & 0,0 & 0,0 \\
Minyak kanola & 0,0 & 4,0 & $(10 \%)$ \\
\hline
\end{tabular}

Keterangan : P0: Ransum kontrol (60\% hijauan:40\% konsentrat); P1: P0 + Minyak Kanola (10\% dari total konsentrat); P2: P0 + Mikroenkapsulasi Minyak Kanola (10\% dari total konsentrat)

Tabel 2. Keseimbangan nitrogen, populasi mikroba, dan karakteristik fermentasi cairan rumen domba jam ke-4

\begin{tabular}{|c|c|c|c|}
\hline \multirow{2}{*}{ Peubah } & \multicolumn{3}{|c|}{ Perlakuan } \\
\hline & P0 & P1 & P2 \\
\hline Protozoa (log sel ml ${ }^{-1}$ ) & $5,41 \pm 0,28^{b}$ & $4,97 \pm 0,13^{\mathrm{a}}$ & $5,02 \pm 0,60^{\mathrm{a}}$ \\
\hline Bakteri total $\left(\log \mathrm{CFU} \mathrm{ml} \mathrm{l}^{-1}\right)$ & $6,65 \pm 0,18$ & $6,50 \pm 0,14$ & $6,64 \pm 0,53$ \\
\hline 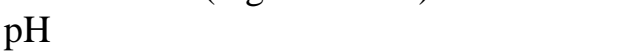 & $6,80 \pm 0,071^{\mathrm{A}}$ & $6,56 \pm 0,05^{\mathrm{B}}$ & $6,80 \pm 0,071^{\mathrm{A}}$ \\
\hline $\mathrm{N}-\mathrm{NH}_{3}(\mathrm{mM})$ & $7,24 \pm 0,94^{\mathrm{B}}$ & $9,19 \pm 1,09^{\mathrm{A}}$ & $5,80 \pm 0,36^{\mathrm{C}}$ \\
\hline VFA total (mM) & $72,63 \pm 17,77$ & $116,24 \pm 57,06$ & $94,53 \pm 48,08$ \\
\hline \multicolumn{4}{|l|}{ Proporsi VFA (\% mM) } \\
\hline $\mathrm{C} 2$ & $58,21 \pm 3,10$ & $59,30 \pm 2,79$ & $57,39 \pm 10,76$ \\
\hline $\mathrm{C} 3$ & $27,93 \pm 3,39$ & $27,88 \pm 1,61$ & $27,60 \pm 8,02$ \\
\hline $\mathrm{nC4}$ & $10,59 \pm 2,63$ & $9,07 \pm 2,15$ & $10,65 \pm 1,89$ \\
\hline iC4 & $1,08 \pm 0,56$ & $0,85 \pm 0,42$ & $0,73 \pm 0,23$ \\
\hline $\mathrm{nC5}$ & $0,85 \pm 0,11$ & $1,17 \pm 0,28$ & $1,69 \pm 1,10$ \\
\hline iC5 & $1,34 \pm 0,44$ & $1,72 \pm 0,96$ & $1,95 \pm 0,43$ \\
\hline Proporsi C2/C3 & $2,11 \pm 0,32$ & $2,13 \pm 0,12$ & $2,37 \pm 1,28$ \\
\hline $\mathrm{CH}_{4}(\mathrm{mM})^{*}$ & $27,79 \pm 6,86$ & $44,35 \pm 22,14$ & $36,29 \pm 20,68$ \\
\hline Produksi $\mathrm{H}_{2} * *$ & $138,44 \pm 32,90$ & $217,60 \pm 102,96$ & $183,60 \pm 99,66$ \\
\hline Penggunaan $\mathrm{H}_{2} * *$ & $56,32 \pm 12,74$ & $85,83 \pm 38,40$ & $67,47 \pm 14,76$ \\
\hline $\mathrm{SPM}\left(\mathrm{mg} \mathrm{m}^{-1}\right)$ & $0,71 \pm 0,03^{\mathrm{B}}$ & $0,82 \pm 0,05^{\mathrm{A}}$ & $0,67 \pm 0,03^{\mathrm{B}}$ \\
\hline $\mathrm{BUN}\left(\mathrm{mg} \mathrm{dl}^{-1}\right)$ & $17,28 \pm 2,29^{\mathrm{ab}}$ & $19,95 \pm 3,15^{\mathrm{b}}$ & $14,94 \pm 2,75^{\mathrm{a}}$ \\
\hline Konsumsi nitrogen (gram ekor ${ }^{-1}$ hari $^{-1}$ ) & $11,57 \pm 1,64^{b}$ & $14,76 \pm 2,44^{\mathrm{a}}$ & $12,14 \pm 1,77^{\mathrm{b}}$ \\
\hline Nitrogen urin (gram ekor ${ }^{-1}$ hari $^{-1}$ ) & $0,70 \pm 0,17$ & $0,96 \pm 0,38$ & $0,68 \pm 0,17$ \\
\hline Nitrogen feses (gram ekor ${ }^{-1}$ hari $^{-1}$ ) & $4,51 \pm 0,21$ & $4,58 \pm 0,66$ & $4,65 \pm 0,52$ \\
\hline Retensi nitrogen (gram ekor ${ }^{-1}$ hari $^{-1}$ ) & $6,36 \pm 1,66^{\mathrm{B}}$ & $9,22 \pm 2,83^{\mathrm{A}}$ & $6,81 \pm 1,98^{\mathrm{B}}$ \\
\hline
\end{tabular}

Huruf yang berbeda pada kolom yang sama menunjukkan perbedaan yang signifikan $(\mathrm{P}<0.05)$ dan sangat signifikan ( $<<0.01)$; P0: Ransum kontrol (60\% hijauan:40\% konsentrat); P1: P0 + Minyak Kanola (10\% dari total konsentrat); P2: P0 + Mikroenkapsulasi Minyak Kanola (10\% dari total konsentrat); Asam asetat; ${ }^{\mathrm{b}} \mathrm{C}_{3}$ : Asam propionat; ${ }^{\mathrm{c}} \mathrm{nC}_{4}$ : Asam butirat; ${ }^{\mathrm{d}} \mathrm{iC}_{4}$ : Asam iso butirat; ${ }^{\mathrm{e}} \mathrm{nC}_{5}$ : Asam valerat; ${ }^{\mathrm{f}} \mathrm{iC}_{5}$ : Asam iso valerat; *= Estimasi menurut rumus Moss et al (2000); **= Estimasi menurut rumus Mitsumori et al (2012); SPM: Sintesis protein mikroba; BUN: Blood urea nitrogen

berkisar antara $10^{5}-10^{6} \mathrm{sel} \mathrm{ml}^{-1}$ cairan rumen. Hasil tersebut lebih tinggi dibandingkan dengan metode secara in vitro yang dilaporkan Hidayah (2014) sebesar 4.00 log sel ml$l^{-1}$ dan $4.28 \mathrm{log}$ sel $\mathrm{ml}^{-1}$ pada penambahan minyak kanola dan mikroenkapsulasi minyak kanola secara in vitro serta Suharti et al. (2017) sebesar 3,85 log sel $\mathrm{ml}^{-1}$ pada penambahan sabun kalsium minyak kanola. Penurunan populasi protozoa menunjukkan bahwa pemberian minyak kanola 
proteksi maupun dalam bentuk mikroenkapsulasi pada taraf $4 \%$ dapat mengganggu kelangsungan hidup protozoa di dalam rumen. Menurut Puastuti (2009), protozoa tidak memiliki daya lipolisis, kondisi rumen yang memiliki banyak lemak akan menyebabkan aktivitas metabolisme protozoa terganggu dan akhirnya protozoa kurang mampu bertahan hidup. Selain itu, menurut Adawiah et al. (2007) penggunaan lemak yang tinggi dalam ransum akan menyelimuti mikroba rumen sehingga mikroba rumen yang tidak memiliki enzim lipolitik seperti protozoa akan mati.

\section{Karakteristik fermentasi rumen}

Penambahan minyak kanola tanpa proteksi pada ransum menghasilkan $\mathrm{pH}$ (Tabel 3) rumen domba paling rendah $(\mathrm{P}<0,01)$ dibandingkan dengan kontrol dan mikroenkapsulasi minyak kanola tetapi $\mathrm{pH}$ rumen masih sesuai dengan Dehority (2005) yaitu sebesar 5,4-7,8 untuk menunjang kondisi rumen yang normal. Penurunan $\mathrm{pH}$ pada rumen domba secara sangat signifikan $(\mathrm{P}<0,01)$ yang diberi minyak kanola tanpa proteksi mungkin disebabkan adanya penurunan secara nyata $(\mathrm{P}<0,05)$ pada populasi protozoa (Tabel 2). Protozoa memiliki peranan penting dalam mempertahankan $\mathrm{pH}$ rumen dengan memanfaatkan karbohidrat yang mudah difermentasi di dalam rumen secara cepat sehingga dapat mencegah efek toksik yan terjadi akibat kelebihan material hasil fermentasi (Dore \& Gouet 1991). Pengaruh pH menurut de Veth \& Kolver (2001) bahwa nilai pH yang berada diluar kisaran 5,7-7,8 akan memberikan dampak negatif pada rumen, sehingga $\mathrm{pH}$ pada penelitian ini masih dalam keadaan normal yang tidak mengganggu fungsi rumen.

Penambahan minyak kanola bebas dalam penelitian ini meningkatkan amonia rumen sedangkan penambahan mikroen-kapsulasi minyak kanola menurunkan kadar amonia dibandingkan kontrol (Tabel 2). Tingginya kadar amonia pada penambahan minyak kanola bebas berkorelasi positif dengan tingginya konsumsi $(\mathrm{P}<0,05)$ nitrogen domba (Tabel 2) yang akan dirombak menjadi amonia di dalam rumen. Bain et al (2014) melaporkan kadar amonia rumen in vitro sebesar 7,29; 7,44; 6,76 untuk minyak kedelai, minyak sawit dan minyak biji bunga matahari. Suharti et al (2017) melaporkan kadar amonia sebesar 11,47
$\mathrm{mM}$ dan 10,49 mM untuk sabun kalsium minyak kanola dan minyak flaxseed. Rendahnya kadar amonia rumen pada perlakuan penambahan mikroenkapsulasi minyak kanola (P2) diduga disebabkan memiliki kandungan rumen undegradable protein (RUP) yang lebih tinggi dibanding kandungan rumen degradable protein (RDP). Beberapa bahan pakan pada perlakuan P1 seperti bungkil kedelai dan dedak padi memiliki kandungan RDP menurut NRC (2001) masing-masing sebesar 65,4\% dan $52,3 \%$. Nilai tersebut lebih tinggi dibandingkan kandungan RDP pada bahan pakan bungkil kelapa yaitu sebesar 27,9\% (Mahesh et al., 2017) yang lebih besar penggunaannya pada ransum P0 dan P1. Kadar amonia pada penelitian ini masih sesuai dengan kisaran normal menurut McDonald (2002) yaitu 6-21 Mm.

Kadar VFA dalam rumen domba tidak dipengaruhi oleh penambahan minyak kanola proteksi maupun tanpa proteksi. Nilai ini masih sesuai dengan McDonald et al. (2002) yang menyatakan kisaran normal VFA total yaitu 70$150 \mathrm{mM}$. Menurut Data pada Tabel 2, penambahan minyak terproteksi maupun tanpa proteksi memiliki rasio asetat dan propionat yang tidak berbeda dengan kontrol yaitu di kisaran 2,11-2,37. Yost et al. (1977) menyatakan, rasio asetat dan propionat maksimal untuk pertambahan bobot badan ternak ruminansia adalah 3:1. Perbedaan ini mungkin disebabkan meningkatnya proporsi asam propionat yang dihasilkan sehingga menurunkan rasio asetat : propionat. Li et al. (2009) melaporkan pemberian asam linolenat dapat menurunkan konsentrasi asetat, meningkatkan konsentrasi propionat, dan menurunkan rasio asetat dan propionat. Selain itu, Hidayah (2014) melaporkan tingginya produksi propionat dan isovalerat diduga karena rendahnya produksi metan $\left(\mathrm{CH}_{4}\right)$ yang disebabkan oleh asam lemak linolenat (C18:3) dari minyak flaxseed yang diproteksi dengan mikroenkapsulasi memiliki sifat slow release sehingga mampu menurunkan aktivitas archae metanogen. Hal ini juga dapat menjelaskan produksi metan yang lebih rendah pada P2 dibanding P1. Produksi $\mathrm{CH}_{4}$ (Tabel 2) tidak berbeda nyata antar perlakuan tetapi cenderung tinggi pada produksi VFA yang tinggi. Hasil ini lebih tinggi dari yang dilaporkan Hidayah (2014) sebesar 19,83 dan 23,50 masing-masing pada minyak kanola tanpa proteksi dan terenkapsulasi secara in vitro. Suharti (2010) 
melaporkan penurunan produksi metan dan peningkatan produksi propionat pada penambahan ekstrak lerak dalam ransum. Baeuchemin \& McGinn (2014) melaporkan penurunan emisi metan sebesar $32 \%$ hari $^{-1} \mathrm{sapi}^{-1}$ dengan pemberian minyak kanola tanpa proteksi karena adanya asam fumarat dalam minyak kanola yang merupakan prekursor metabolik dari $\mathrm{C} 3$ dan dapat memberikan $\mathrm{H}_{2}$ alternatif di dalam rumen. Hal ini sesuai dengan Moss et al. (2000) yang menyatakan bahwa produksi metan dan propionat merupakan jalur yang menggunakan $\mathrm{H}_{2}$ sehingga semakin rendahnya produksi metan dan propionat maka akan menurunkan penggunaan $\mathrm{H}_{2}$ dan sebaliknya akan meningkatkan penggunaan $\mathrm{H}_{2}$. Pada penelitian ini, meningkatnya proporsi propionat (Tabel 2) dalam total VFA tidak menurunkan produksi metan.

\section{Sintesis Protein Mikroba, BUN, dan Retensi Nitrogen}

Kandungan SPM (Tabel 2) rumen pada ternak yang diberi minyak kanola tanpa proteksi meningkat sangat signifikan $(\mathrm{P}<0,01)$ dibandingkan kontrol dan lebih tinggi dibandingkan dengan pemberian mikroenkapsulasi minyak kanola. Hasil ini lebih tinggi dibandingkan dengan Tiven et al. (2011) yang menggunakan crude palm oil (CPO) 3\% sebesar $0,10 \mathrm{mg} \mathrm{ml}^{-1}$. Suryapratama \& Suhartati (2012) melaporkan peningkatan SPM pada pemberian minyak tanpa proteksi sebesar $18,36 \%$ pada pemberian minyak kedelai sebesar 3\%. Peningkatan disebabkan kandungan amonia $(\mathrm{P}<0,01)$ dan VFA dalam rumen yang lebih tinggi pada pemberian minyak kanola tanpa proteksi Protein yang terkandung dalam ransum sebagian besar akan terdegradasi di dalam rumen. Proses degradasi protein merupakan proses pembentukan asam $\alpha$ keto dan amonia melalui proteolisis dan deaminasi oleh bakteri rumen (McDonald et al., 2002). Amonia yang terbentuk dari perombakan protein juga digunakan untuk sintesis protein mikroba. Kadar SPM pada perlakuan penambahan mikroenkapsulasi minyak kanola (P2) disebabkan rendahnya kadar amonia rumen domba sehingga pembentukan protein mikrobial juga terhambat. Kadar amonia cairan rumen yang rendah akan membatasi perkembangan populasi mikroba rumen terutama bakteri karena amonia dibututuhkan oleh bakteri sebagai sumber $\mathrm{N}$ untuk membangun sel tubuhnya.
BUN merupakan salah satu indikator yang dapat digunakan untuk mengetahui efisiensi penggunaan protein dan kecukupan energi (Tahuk et al., 2008). Pada penelitian ini perlakuan penambahan minyak kanola tanpa proteksi (P1) secara nyata meningkatkan $(\mathrm{P}<0,05)$ kadar BUN dibandingkan dengan kontrol (P0). Nilai BUN pada penelitian ini masih sesuai dengan Swenson (1977) yang menyatakan kadar urea darah domba yang normal berada pada kisaran 13-28 $\mathrm{mg} \mathrm{dl}^{-1}$. Tingginya kadar BUN pada penelitian ini memiliki korelasi yang tinggi dengan kadar amonia $\left(\mathrm{NH}_{3}\right)$ dalam rumen dimana perlakuan penambahan minyak kanola murni (P1) menghasilkan kadar amonia dan BUN tertinggi serta pada P2 semakin menurunkan kadar amonia dan BUN dibanding kontrol. Hal ini sesuai McDonald et al. (2002) yang menyatakan kadar urea darah dapat dipengaruhi oleh kadar amonia dalam rumen. Terdapat keterikatan antara kadar amonia rumen, SPM, dan BUN. Menurut Orskov (1992) ketersediaan energi menjadi faktor penentu efisiensi pemanfaatan amonia untuk sintesis protein mikroba. Konsumsi nitrogen yang melebihi kapasitas bakteri mensintesis protein mikroba maupun keterbatasan sumber energi mikroba dapat meningkatkan kadar urea darah karena tingginya amonia yang bebas di dalam rumen. Ranjihan (1981) menambahkan absorbsi amonia yang dibawa ke hati akan berlebihan jika kadar amonia di dalam rumen tinggi, sehingga perombakan amonia menjadi urea kalah cepat. Sejalan dengan kadar BUN, retensi nitrogen pada $\mathrm{P} 1$ juga menghasilkan retensi yang tinggi $(\mathrm{P}<0,01)$ dibanding kontrol dan $\mathrm{P} 2$. Retensi nitrogen merupakan protein yang dimanfaatkan oleh tubuh ternak. Nilai retensi nitrogen didapatkan dari selisih nitrogen yang dikonsumsi dengan nitrogen yang dikeluarkan feses dan urin. Hasil penelitian ini lebih rendah dari penelitian Sari (2012) dengan retensi nitrogen sebesar 7,42-9,00 g ekor $^{-1}$ hari $^{-1}$ pada domba yang mengandung $1,5 \%$ minyak jagung dan minyak ikan lemuru dalam ransum. Penambahan minyak dalam ransum menghasilkan nilai retensi nitrogen yang positif. Purbowati (2001) menyatakan bahwa nitrogen dalam ransum mencukupi kebutuhan ternak, maka ternak tidak perlu merombak jaringan tubuh untuk memenuhi kebutuhannya sebagai konsekuensi atas hilangnya pada proses pencernaan. 


\section{KESIMPULAN}

Penambahan minyak kanola sebesar $4 \%$ dalam bentuk bebas maupun mikroenkapsulasi minyak kanola menurunkan populasi protozoa dan mempengaruhi kadar amonia dalam rumen domba. Dalam bentuk bebas, minyak kanola mampu meningkatkan retensi nitrogen, amonia, kadar SPM dan BUN. Pemberian minyak kanola bebas maupun proteksi tidak memberikan dampak negatif pada penurunan bakteri total.

\section{DAFTAR PUSTAKA}

Adawiah, T. Sutardi, T. Toharmat, W. Manalu, N. Ramli, \& U.H. Tanuwiria. 2007. Respons terhadap suplementasi sabun mineral dan mineral organik serta kacang kedelai sangrai pada indikator fermentabilitas ransum dalam rumen domba. Med. Pet. 30:63-70.

Agnihotri, N., R. Mishra, C. Goda, \& M. Arora. 2012. Microencapsulation-A novel approach in drug delivery: a review. Indo Global J. of Phram. Sci. 2:1-20.

Baeuchemin, K.A., \& S.M. McGinn. 2014. Methane emissions from beef cattle: effects of fumaric acid, essential oil, and canola oil. J Anim Sci. 84:1489-1496.

Bain, A., I.K.G. Wiryawan, D.A. Astuti, S. Suharti, \& C. Arman. 2014. Effect of protected vegetable oils on in vitro fermentation characteristics and nutrient digestibility of bali cattle rumen fluid. Di dalam Sustainable Livestock Production in the Perspective of Food Security, Policy, Genetic Resources and Climate Change. Proceedings of the 16th AAAP Animal Science Congress Vol. II 10-14 November 2014, Gadjah Mada University, Yogyakarta, Indonesia. pp. 308-311.

Bhatt, R.S., S.A. Karim, A. Sahoo, \& A.K. Shinde. 2013. Growth performance of lambs fed diet supplemented with rice bran oil as such or as calcium soap. Asian-Aust. J. Anim. Sci. 26(6):812-819.

Calvo, P., T. Hernández, M. Lozano, \& D. González-Gómez 2010. Microencapsulation of extra-virgin olive oil by spray-drying: Influence of wall material and olive quality. European $\mathbf{J}$ of Lipid Science and Technology 112(8):852-858.

Carneiro, C.F.H., V.R. Tonon, R.F.C. Grosso, \& D.M Hubinger. 2013. Encapsulation efficiency and oxidative stability of flaxseed oil microencapsulated by spray drying using different combination of wall materials. J Food Eng. 115:351-443.

Dehority, B.A. 2005. Effect of pH on viability of Entodinium caudatum, Entodinium exiguum, Epidinium caudatum, and Ophryoscolex purkynjei in vitro. $\mathbf{J}$. Eukaryotic Microbiol. 52:39-342.

de Veth, M.J., \& E.S. Kolver. 2001. Diurnalvariation in $\mathrm{pH}$ reduces digestion and synthesis of microbial protein when pasture is fermented in continuous culture. J. Dairy Sci. 84:2066-2072.

Dore, J., \& P.H. Gouet. 1991. Microbial Interaction in the Rumen. In: Jouany, ed. Rumen Microbial Metabolism and Ruminant Digestion. INRA, Paris. pp. 71-88.

[GLP] General Laboratory Procedures. 1966. Report of Dairy Science. University of Wisconsin. Madison (USA).

Hess, B.W., G.E. Moss, \& D.C. Rule. 2008. A decade of developments in the area of fat supplementation research with beef cattle and sheep. J Anim Sci. 86: E188-E204.

Hidayah, N. 2014. Ketahanan biohidrogenasi minyak nabati yang diproteksi dengan metode sabun kalsium dan mikroenkapsulasi secara in vitro. Tesisi. Program Studi Ilmu Nutrisi dan Pakan. Sekolah Pascasarjana. Institut Pertanian Bogor. Bogor.

Hidayah, N., S. Suharti, \& I.K.G. Wiryawan. 2014. In vitro rumen fermentation of ration supplemented with protected vegetable oil. Media Peteternakan 37(2):129-135.

Kearl LC. 1982. Nutrition Requirement of Ruminant in Developing Countries. Utah State University. Logan Utah (US).

Kanakdande, D., R. Bhosale, \& R.S. Sinnghal. 2007. Stability cumin oleoresin microencapsulation in different combination of gum arabic, maltodextrin, and 
modified starch. Carbohydrate Polymer 67:536-541.

Li, X.Z., S.H. Choi, G.L. Jin, C.G. Yan, R.J. Long, C.Y. Liang, \& M.K. Song. 2009. Linolenic acid in association with malate or fumarate increased CLA production and reduced methane generation by rumen microbes. Asian-Aust. J Anim. Sci. 22(6):819-826.

Lowry, O.H., N.J. Rosenbrough, A.L. Farr, \& R.J. Randall. 1951. Protein measurement with the folin phenol reagent. J Bioi Chern. 193:265-275.

Maeng, W., J. Park, \& H.J. Kim. 1997. The Role of Carbohydrate Supplementation in Microbial Protein Synthesis in the Rumen. In: Onedera, R. H. Itabashi, K. Ushida, H. Yano and Y. Sasaki (Eds.), Rumen Microbes and Digestive Physiology in Ruminants. Japan Scientific Societies Pr. Tokyo.

Mahesh, M.S., S.S. Thakur, R. Kumar, T.A. Malik, \& R. Gami. 2017. Nitrogen fractionation of certain conventional- and lesser-known by-products for ruminants. J Anim Nut. 3:186-190.

Maia, M.O., I Susin, E.M. Ferreira, C.P. Nolli, T.S. Gentil, A.V. Pires, \& G.B. Mourão. 2012. Intake, nutrient apparent digestibility and ruminal constituents of sheep fed diets with canola, sunflower or castor oils. R. Bras. Zootec. 41(11): 2350-2356

Makkar, H.P.S., O.P. Sharma, R.K. Dawra, \& S.S. Negi. 1982. Simple Determination of microbial protein in rumen liquor. $\mathbf{J}$ of Dairy Sci 65(11):2170-2173.

Martin C, J Rouel, J.P Jouany, M Doreau , Y Chilliard . 2008. Methane output and diet digestibility in response to feeding dairy cows crude linseed, extruded linseed, or linseed oil J. Anim. Sci. 86: 2642-2650.

McDonald, P., R.A. Edward, J.F. Greenhalgh, \& C.A. Morgan. 2002. Animal Nutrition. Ed. ke-6. John Wiley and Sons Inc. New York.

Mitsumori, M., T. Shinkai, A. Takenaka, O. Enishi, K. Higuchi, Y. Kobayashi, I. Nonaka, N. Asanuma, S.E. Denman, \& C.S. McSweeney. 2012. Responses in digestion, rumen fermentation and microbial populations to inhibition of methane formation by a halogenated methane analogue. The British J. Nutr. 108(3):482-491.

Moss, A.R., J.P. Jouany, J. Newbold. 2000. Methane production by ruminants: its contribution to global warming. Ann Zootech. 49:231-253.

NRC.2001. Nutrient requirements of dairy cattle. Ed 7. National Academic Press. Washington DC.

Ogimoto, K., \& S. Imai. 1981. Atlas of Rumen Microbiology. Japan Scientific Soc Pr. Tokyo.

Orskov, E.R. 1992. Protein Nutritional in Ruminant. Academic Press. London.

Preston, T.R. 1986. Better utilization of crop residues and by-products in animal feeding: Research Guidelines. 2. A practical manual for research workers. Rome (ITA): Food and Agriculture Organization of the United Nations (FAO):20-35.

Puastuti, W. 2009. Manipulasi bioproses dalam rumen untuk meningkatkan penggunaan pakan berserat. Wartazoa 19(4):180-190.

Purbowati, E. 2001. Balance energy dan nitrogen domba yang mendapat berbagai aras konsentras dan pakan dasar yang berbeda. Prosiding Seminar Nasional Teknologi Peternakan dan Veteriner. Bogor November 2001. Pusat Penelitian dan Pengembangan Peternakan. Bogor. Hlm 292-300.

Ranjihan, S.K. 1981. Animal Nutrition in Tropics. Second Revised edition. Vikas Publishing House PVT LTD. New Delhi.

Sari, D.O. 2012. Fermentabilitas, populasi protozoa, alantoin urin, dan neraca nitrogen domba lokal calon induk yang diberi sumber asam lemak tak jenuh berbeda. Institut Pertanian Bogor. Bogor.

Soebarinoto, S. Chuzaeni, \& Mashudi. 1991. Ilmu Gizi Ruminansia. Universitas Brawijaya. Malang.

Soltan, Y.A., A.S. Natel, R.C. Araujo, A.S. Morsy, \& A.L. Abdalla. 2018. Progressive adaptation of sheep to a 
microencapsulated blend of essential oils: Ruminal fermentation, methane emission, nutrient digestibility, and microbial protein synthesis.

Suharti, S., A.R. Nasution, \& I.K.G. Wiryawan. 2017. In vitro rumen fermentation characteristics and fatty acid profiles added with calcium soap of canola/flaxseed oil. Media Peternakan 40(3):171-177.

Suharti, S. 2010. Modifikasi keragaman mikroba dan fermentasi rumen sapi dengan pemberian saponin lerak (Sapindus rarak). Tesis. Institut Pertanian Bogor. Bogor.

Suryapratama, W., \& Suhartati F.M. 2012. Increasing rumen microbial protein synthesis with additional dietary substrate of Saccharomyces cerevisiae and soybean oil. Anim Product. 14(3): 155-159.

Swenson, M.J. 1977. Blood circulation and the cardiovascular system in dukes physiology of domestic animals. Ed 9. Comstock Publishing Associates. Ithaca and London.

Tahuk, P.K., E. Baliarti, \& H. Hartadi. 2008. Keseimbangan nitrogen dan kandungan urea darah kambing bligon pada penggemukan dengan level protein yang berbeda. J Indon Anim Agric 33(4):290298.

Tiven, N.C., L.M. Yusiati, Rusman, \& U. Santoso. 2011. Ketahanan asam lemak tidak jenuh dalam crude palm oil terproteksi terhadap aktivitas mikrob rumen domba in vitro. Media Peternakan 34:42-49.

Wina, E., \& I.W.R. Susana. Manfaat lemak terproteksi untuk meningkatkan produksi dan reproduksi ternak ruminansia. Wartazoa 23(4):176-184.

Yost, W.M., J.W. Young, S.P. Schmidt, \& A.D. McGilliard. 1977. Gluconeogenesis in ruminants: propionic acid production from a high-grain diet fed to cattle. J Nutr 107:2036-2043.

Zhang, C.M., Y.Q. Guo, Z.P. Yuan, Y.M. Wu, J.K. Wang, J.X. Liu, \& W.Y. Zhu. 2008. Effect of octadeca carbon fatty acids on microbial fermentation, methanogenesis and microbial flora in vitro. J Anim Feed Sci and Tech. 146: 259-269. 
Mawar et al./Jurnal Ilmu dan Teknologi Peternakan Tropis 6(3):358-366 